\title{
Komunisme: Sikap Di Hulu dan Di Hilir
}

Shohibul Anshor Siregar

| Situasi ini sebenarnya sudah menggiring rakyat dengan pembelahan sistematis dan ini sangat mudah melahirkan tikai horisontal | Jika yang dimobilisasi melawan komunisme itu adalah umat beragama, maka secara internal agama-agama itu pun akan mengalami keterpilahan penganut yang parah pula | Antara satu dan lain agama (Islam, Protestan, Katholik, Hindu, Budha dan Kong Hu Chu) pastilah akan berbeda pula penyikapannya berhubung temali sejarah konflik perebutan "hak asuh atas Negara" dan konten pemahaman teologisnya masing-masing |

Bulan April lalu sepucuk surat terbuka kepada Presiden RI Joko Widodo tentang 1965 ditandatangani oleh Nursyahbani Katjasungkana Sungkono. la menulis surat itu atas nama International People's Tribunal (IPT) 1965 dan dalam kapasitas dua jabatan lainnya (Koordinator IPT 1965 dan Ketua Yayasan IPT 1965). Dalam surat itu disebutkan bahwa gabungan aktivis masyarakat sipil Indonesia dan internasional pada tanggal 10 -14 November 2015 lalu telah menggelar Tribunal Rakyat Internasional (IPT) 1965. IPT 1965 bertujuan menggalang kesaksian dan bahan bukti kuat dari para korban maupun para pakar mengenai Peristiwa 1965 dan sesudahnya, yang dinyatakan sebagai kejahatan HAM berat. Dikatakan bahwa selain dipimpin para profesional dan ahli yang berpengalaman dalam bidangnya, IPT 1965 juga dihadiri Komisioner Komnas HAM dan Komnas Perempuan. Kedua lembaga ini disebut telah mengonfirmasi data-data yang dikemukakan oleh korban dan para ahli sesuai dengan laporan yang telah mereka buat 4 tahun lalu.

Pokok penting surat itu ialah ekspresi sangat menyesalkan sikap pemerintah yang tidak bermaksud meminta maaf kepada para korban, serta menutup kemungkinan penyelesaian melalui jalur hukum (pro justitia). Padahal, menurut Nursyahbani Katjasungkana Sungkono, Dewan Hakim IPT 1965 telah menyimpulkan bahwa Negara Republik Indonesia bertanggungjawab atas terjadinya kejahatan kemanusiaan, karena telah membuat rantai komando yang terorganisasi lewat badan-badan institusional dari lapisan atas hingga lapisan bawah masyarakat.

Ketika akan menulis artikel ini saya tertarik dengan beberapa judul berita pada sebuah media terkait saat searching di internet Sabtu malam pekan lalu. Judul pertama bunyinya begini: "PDIP Minta BIN Buru Pihak Penghembus Kabar PKI Bangkit Kembali". Judul kedua "Kivlan Sebut PKI Gaya Baru Dipimpin Anak dari Lukman Njoto”. Judul ketiga "Kivlan Zen Ungkap Tokoh Ini di Balik Lahirnya PKI Gaya Baru”. Judul keempat "Soal PKI, Kivlan Zen dan Habib Rizieq Bertemu Menteri Luhut”. Judul kelima "Ribuan Umat Islam Geruduk Istana Tolak Negara Minta Maaf ke PKI". Judul keenam "Yasonna Pesimis Pemerintah Tampung Simposium Tandingan Soal PKI".

Kita ingat bahwa setelah berulangkali terjadi semacam testing on the water melalui kemunculan rentetan aktivitas berindikasi komunisme di berbagai daerah di Indonesia. Seolah dirangkai sedemikian rupa, maka pada tanggal 18-19 April 2016 sebuah Simposium Nasional bertema “Membedah Tragedi 1965, Pendekatan Kesejarahan" diselenggarakan di Jakarta. Tidak tanggung-tanggung, Ketua Panitia Pengarah ialah Gubernur Lemhanas Letjen TNI Purn Agus Widjojo. Sejumlah menteri juga hadir, di 
antaranya Menteri Dalam Negeri Tjahjo Kumolo, Menteri Hukum dan Hak Asasi Manusia Yasonna Laoly, Menteri Koordinator Bidang Politik, Hukum, dan Keamanan Luhut Binsar Pandjaitan, Jaksa Agung Muhammad Prasetyo. Simposium ini bertujuan untuk meletakkan persitiwa 1965 dengan benar dalam perspektif sejarah.

Ketika membacakan puisi pada Simposium ini, ia diteriaki dan kemudian diusir. Taufik Abdullah adalah salah satu di antara banyak tokoh terkemuka di Indonesia yang menolak memberi angin atas hidupnya kembali komunisme di Indonesia. Puisi apa yang dibacakannya dalam Simposium itu? Ini sedikit petikannya:

"Katanya ada partai di dunia itu membantai 120 juta orang, selama 74 tahun di 75 negara. Kemudian kata Aida dan Rania, ya..ya..120 juta orang yang dibantai. Setiap hari mereka membantai 4500 orang selama 74 tahun di 75 negara. Kemudian cucuku bertanya. Datuk-datuk, kok ada orang begitu ganas? Kemudian dia bertanya lagi, kenapa itu datuk? Mengapa begitu banyak? Mereka melakukan kerja paksa, merebut kekuasaan di suatu Negara. Kerja paksa. Kemudian orang-orang di bangsanya sendiri berjatuhan mati. Kerja paksa. Kemudian yang ke dua. Sesudah kerja paksa. Program ekonomi diseluruh negara komunis tidak ada satupun yang berhasil. Mati kelaparan, bergelimpangan di jalan-jalan. Kemudian yang ketiga. Sebab jatuhnya Puisi ini. Sebabnya adalah mereka membantai bangsanya sendiri. Mereka membantai bangsanya sendiri. Di Indonesia. Pertamakali di bawa oleh Musso, di bawa Musso. Di Madiun mereka mendengarkan pembantaian”.

Sebetulnya pro dan kontra mengenai kasus ini sudah cukup lama. Diketahui Presiden SBY juga pernah mengajukan gagasan memberi maaf kepada korban peristiwa 1965 , dan sebagaimana kepada Presiden Jokowi, mayoritas rakyat kiranya menolak hal itu dilakukan. Kata Goenawan Moehammad, pada pertengahan Maret 2000 Gus Dur sebetulnya pernah melakukan permintaan maaf juga kepada para korban. Namun Pramoedya Ananta Toer menolak meski tokoh lain, Oey Hay Djoen, tokoh Lekra, penerjemah Das Kapital, mempertanyakan sikap itu dengan berkata "apa hak moral kita untuk menolak itu”.

Dari pro dan kontra itu kemudian Goenawan Moehammad berucap demikian:

"Maka apa arti permintaan maaf pemerintah sekarang-andai kata pemerintah setuju untuk mengutarakannya atas kekejaman pasca 1965? Mula-mula, ada yang harus diurai. Belum jelas mengapa pemerintah yang sekarang wajib minta maaf, atau mengapa Kepala Negara hari ini, Joko Widodo-laki-laki yang baru berumur lima tahun ketika kekejaman di pertengahan 1960-an itu terjadi-harus minta maaf untuk itu. Benarkah "Negara" yang sekarang identik dengan "Negara" yang berkuasa pada 1966, dan sebab itu menanggung dosa yang sama? Bisakah pendekatan legal sematamata berlaku, yang melihat subyek, dalam hal ini Negara, sebagai identitas yang tak berubah?"

Rekonsiliasi yang selalu dituntut di balik permintaan maaf resmi pemerintah itu sebetulnya sudah terjadi, kecuali jika yang dimaksud dengan rekonsiliasi itu hanyalah peluang besar membalaskan dendam kepada para pihak yang dituduh pernah melakukan kekerasan yang mereka kategorikan sebagai pelanggaran HAM berat 
kepada para korban tragedi 1965 itu. Selanjutnya tindakan projustisia digelar, menyeret orang-orang yang dinyatakan berperan dalam peristiwa itu, sembari menancapkan stigma anti HAM kepada gerakan-gerakan perlawanan terhadap PKI.

Sejarawan Anhar Gonggong dengan tegas mengritik kesalahan cara berfikir dan niat tersembunyi di balik tuntutan permintaan maaf itu. Aturan hukum terkait sikap resmi Negara terhadap bentuk-bentuk yang dapat dikategorikan mensosialisasikan faham komunisme di Indonesia sudah jelas, dan sangat salah jika memojokkan aparat Negara (Kepolisian dan TNI) jika melakukan apa yang diamanahkan oleh hukum. Bagi Anhar Gonggong kesalahan besar para pengusul permintaan maaf Negara terhadap korban kekerasan 1965 ialah ketika mereka menganggap satu-satunya kekerasan yang dialami oleh bangsa Indonesia ialah tragedi 1965 itu. Seakan-akan yang bersalah itu hanyalah TNI, NU, Muhammadiyah dan rakyat yang melakukan pemberangusan terhadap PKI.

Komunisme itu berbahaya. Bertentangan dengan Pancasila. Bagaimana cara membendungnya? Ini pekerjaan sangat susah, meski banyak klaim akadenis yang sudah menyatakan ideologi ini sudah bangkrut sama sekali dan tak punya daya tarik, sebagaimana Salim Said menyatakan. Tetapi ini bukan urusan akademis semata. Ada nuansa hasrat pembalasan dendam yang tak terperikan. Jika di Jakarta kelihatannya begitu riuh, maka apa yang patut dikerjakan di daerah untuk menangkal tumbuhberkembangnya faham komunisme ini kembali? Sinergitas Pemerintah Daerah dengan umat beragama dalam menghempang faham komunisme. Itu perlu sekali. Tetapi apakah hal itu mungkin dilakukan?

Mengapa saya berpendapat sinergitas itu tak mungkin? Dalam pemahaman saya perkembangan yang sedang terjadi bukanlah sebuah peristiwa sederhana. Ini perkerjaan elit. Elit sekali. Karena itu pula tak mungkin Pemerintah Daerah berbuat apa-apa tentang itu dalam sistem pemerintahan, politik dan demokrasi yang amat sentralistik seperti sekarang. Ditambah lagi dengan fakta demokratisasi yang melangkah surut jauh sekali ke belakang, seolah akan dicabut segera dari akar persemaiannya yang sempat bersemi seketika dan kemudian sirna.

Dengan melihat keriuhan tentang isyu komunisme ini, di Jakarta, di pusat pemerintahan, kiranya dapat disimpulkan bahwa hanya orang berkecerdasan amat tinggi dan dengan referensi pengalaman getir masa lalulah yang dapat faham apa sebenarnya yang sedang terjadi. Kepala Daerah itu paling-paling secara diam-diam mendorong umat beragama untuk melakukan sesuatu, jika ia anti komunisme. Sedangkan Kepala Daerah yang pro komunisme tentu akan berusaha bertindak sebaliknya. Apa sebab? Kepala Daerah itu umumnya hanyalah pembebek, hipokrit dan tak memiliki orientasi ideologis yang jelas karena lebih tertarik pada hal-hal pragmatis semenjak pada masa paling dini ia terpikir untuk ikut dalam kompetisi perebutan jabatan Kepala Daerah. Dalam kondisi itu umumnya kesibukannya hanyalah memikirkan ketak-terdeteksian kerugian daerah karena ulahnya. Ini jika ingin berterus terang. Tentu ada sejumlah kecil yang teguh dan dengan kepiawaiannya bisa bermain aman dalam sistem yang sangat buruk.

Situasi ini sebenarnya sudah menggiring rakyat dengan pembelahan sistematis dan ini sangat mudah melahirkan tikai horisontal. Jika yang dimobilisasi melawan komunisme 
itu adalah umat beragama, maka secara internal agama-agama itu pun akan mengalami keterpilahan penganut yang parah pula. Antara satu dan lain agama (Islam, Protestan, Katholik, Hindu, Budha dan Kong $\mathrm{Hu} \mathrm{Chu)} \mathrm{pastilah} \mathrm{akan} \mathrm{berbeda}$ pula penyikapannya berhubung temali sejarah konflik perebutan "hak asuh atas Negara" dan konten pemahaman teologisnya masing-masing. Lagi pula, dugaan afiliasi keagamaan untuk beroleh sebuah rumah perlindungan aman semasa pengejaran terhadap para aktivis komunis di Indonesia tempohari bukanlah isapan jempol. Sebagian mungkin telah menemukan pertaubatannya sebelum meninggal. Tetapi berapa banyak mereka yang tetap melakukan penggalangan secara rahasia kepada para pengikut baru? Tak seorang pun mampu menghitungnya.

Anda masih ingat ketika tahun 1960 Bung Karno tampil segagah-gagahnya dengan gagasan nasakom (nasionalisme, Agama dan Komunisme) yang dengan demikian peran PKI sebagai mitra "junior" dalam pemerintahan resmi dilembagakan? Bagaimana menyatukan ketiga komponen itu dalam satu nafas? Itulah Bung Karno, dan asesmentnya terhadap living reality di sekitarnya sembari menggantang kekuasaan abadi di dalamnya. Apakah ada perbandingan yang dapat dibuat dari kondisi itu dengan sekarang? Jangan-jangan sesuatu yang ditunggu sekarang hanyalah konflik horisontal di antara sesama anak bangsa. Lalu siapa beruntung?

Shohibul Anshor Siregar Naskah ini pertamakali diterbitkan oleh Harian Waspada Medan, Selasa, 12 Juli 2016, hlm B8 